\title{
MOVIMENTOS DE MUDANÇA POLÍTICA NA AMÉRICA DO SUL CONTEMPORÂNEA ${ }^{1}$
}

\author{
Marcelo Coutinho
}

\begin{abstract}
RESUMO
Desde as últimas décadas do século XX, a América do Sul passa por profundas mudanças politicas e econômicas que a tornaram mais democrática e liberal. Contudo, os processos de democratização política e liberalização econômica não convergiram espontaneamente na região. Ao contrário, esses dois processos estruturais apresentaram grandes incompatibilidades. Em resposta à agenda neoliberal, hegemônica durante os anos 1990, novos líderes e governos surgiram na virada de século com tendências mais nacionalistas e à esquerda do espectro político, porém marcando um movimento muito mais heterogêneo em comparação com a uniformidade observada na década imediatamente anterior. $O$ artigo predispõe-se a descrever e explicar brevemente esses movimentos e contra-movimentos sul-americanos com o argumento de que a ascensão de novas lideranças ao poder nada mais é do que uma maneira plural de as sociedades tentarem reagir, pelo voto, a essa contradição de sua época. O artigo realiza uma breve discussão sobre a elevação e a queda do neoliberalismo na região, os limites do nacionalismo que passa então a emergir e os desdobramentos populistas do institucionalismo periférico. O artigo conclui sugerindo que a divisão analítica convencional na área entre institucionalismo e populismo, ou entre neoliberalismo e modelos nacionalistas anacrônicos, não deve levar o debate teórico nem as democracias na prática para muito longe. Na realidade, as contradições vividas nas últimas décadas estão redefinindo a política na América do Sul, para o novo século, de uma forma inédita e cujo resultado final é imprevisível.
\end{abstract}

PALAVRAS-CHAVE: política sul-americana; mudança política; democracia na América Latina; neoliberalismo; populismo; nacionalismo; institucionalismo.

\footnotetext{
"O liberalismo econômico havia começado uma centena de anos antes e fora enfrentado por um contra-movimento protecionista que atingia, agora, o último bastião da economia de mercado. Um novo conjunto de idéias dominantes desbancava o mundo do mercado auto-regulável. Para estupefação da grande maioria dos contemporâneos, forças insuspeitadas de liderança carismática e de isolacionismo autárquico irromperam e uniram as sociedades sob novas formas".'(Polanyi, 1980, p. 137).
}

\section{INTRODUÇÃO}

Um dos maiores problemas da América do Sul contemporânea é que, desde sua democratização política e liberalização econômica nas últimas décadas do século XX, seus governos nacionais vêm sendo eleitos pelas "ruas", com os votos oriundos sobretudo das populações menos privilegia-

\footnotetext{
1 Este artigo é resultado de pesquisas desenvolvidas no âmbito do Observatório Político Sul-Americano (OPSA) do Instituto Universitário de Pesquisas do Rio de Janeiro (Iuperj). Para a organização dos dados, contou com a valiosa assistência de Juan Claudio Epsteyn e Flávio Pinheiro.
}

das, mas, ainda assim, querem ou simplesmente são forçados a agir em maior sintonia com os "mercados" e com todas as exigências de reformas e ajustes a um mundo cada vez mais globalizado e interdependente que isso implica. Desse modo, caracterizado na região como um estelionato eleitoral em que a expectativa dos eleitores em termos de políticas públicas é deliberadamente frustrada pelos novos governos, o policy switch é conseqüência, em grande parte, de um processo político contraditório (WEYLAND, 1996; STOKES, 2001).

Essa contradição, que está na base de grande parte das crises políticas na região nos últimos 20 
anos, é resultado de movimentos de mudança que não ocorrem somente na América Latina, mas que nela assumem proporções bastante nítidas, com variações significativas entre os países (COUTINHO, 2005; 2006). Tal contradição é mais forte ou se manifesta mais claramente nos Andes do que no Cone Sul; em parte porque neste último o sistema partidário conseguiu sobreviver ao longo dos anos e, com isso, oferecer um canal mais institucionalizado de expressão dos conflitos, capaz de incluir novos atores políticos e sociais, bem como intermediar suas relações com os poderes públicos, normalizando, assim, a vida democrática.

O dilema posto entre os mercados e as ruas é, obviamente, uma metáfora que não busca dividir a sociedade em duas partes monolíticas ou estanques e muito menos ignorar os setores intermediários e as classes médias. Deve servir somente como uma representação parcimoniosa para um fenômeno bastante conhecido desde o século XIX que opõe o capital ao trabalho - segundo uma interpretação marxista - ou a elite ao povo segundo vertentes mais ligadas ao populismo - , mas que hoje na América do Sul adquire conotações próprias. Enfim, trata-se de uma metáfora que ajuda a esclarecer transformações e antagonismos que se adensaram na região na virada de século graças à centralidade assumida tanto pelos mercados pós-liberalização quanto pelas forças populares com a transição para a democracia, o que provocou, como conseqüência, choques entre distintos setores da sociedade que não necessariamente compartilham os mesmos valores e interesses $^{2}$.

Nem o liberalismo econômico tampouco a democracia são fenômenos novos. $\mathrm{O}$ institucionalismo costuma lidar com eles como se fossem dois lados da mesma moeda: inter-relacionados e compatíveis. Não à toa, o institucionalismo no campo das Relações Internacionais é chamado de liberalismo, e está geralmente em oposição às correntes realistas (BALDWIN, 1993). Isso acontece porque a democracia e a cooperação entre as nações guardariam uma boa dose de teor liberal (ou institucional),

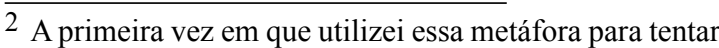
esclarecer os conflitos existentes nas sociedades sul-americanas contemporâneas foi em artigo publicado em 3 de outubro de 2005, no Jornal do Brasil, intitulado "O mercado e as ruas".
}

sem o que, supostamente, nenhuma das duas prosperaria $^{3}$. Este teor liberal tenta minimizar os conflitos existentes tanto na sociedade, entre os mercados e as ruas, quanto no convívio entre países de maneira geral, mas muito especialmente entre aqueles de diferentes níveis de desenvolvimento e regimes políticos.

Do ponto de vista doméstico, ao ignorar os conflitos pelo menos potenciais entre o mercado e as ruas, o institucionalismo gera, mesmo sem querer, o que mais teme de acordo com os seus próprios termos, isto é, o populismo nacionalista. Em alusão ao mundo analisado por Polanyi (1980), é possível verificar hoje, como no passado, que a um movimento de liberalização seguiu-se novamente outro contra-movimento de restauração ou no qual a idéia de mercado auto-regulável é substituída por um pensamento e políticas mais desenvolvimentistas, estejam estas inseridas no ideário do socialismo ou simplesmente no do protecionismo.

Para fins analíticos, a história recente da América do Sul pode ser dividida em dois tempos. O primeiro, vai do final dos anos 1970 aos anos 1990, e marca a substituição de regimes autoritários e do nacional-desenvolvimentismo, que já existia antes mesmo dos governos militares, em favor da democracia e da liberalização econômica. O segundo, do final dos anos 1990 aos anos 2000, refere-se, por outro lado, a uma reação popular nas urnas e nas ruas contra mais de uma década de reformas em direção ao mercado, que não lograram transformar significativamente as estruturas sociais de pobreza e desigualdade encontradas na região. Cada um desses movimentos traz consigo novas lideranças e sua própria dinâmica, o que permite uma análise separada, ainda que seus elementos estejam associados.

\footnotetext{
3 Vale notar que a agenda liberal de reformas direcionadas ao mercado iniciada nos anos 1980 e que se tornou hegemônica nos anos 1990 coincidiu, temporalmente, com o fortalecimento do neo-institucionalismo na Ciência Política, principalmente nos Estados Unidos. Até então, as instituições estavam ausentes das principais correntes teóricas e trabalhos acadêmicos entre 1950 e 1980, incluindo as do campo de Relações Internacionais, o que demonstra um paralelismo entre essa nova abordagem institucional e as novas práticas políticas em andamento. De maneira precoce, o Chile foi o primeiro país na América Latina a adotar, a partir de 1973, uma agenda de liberalização fortemente influenciada pela escola econômica de Chicago.
} 
Sendo assim, a divisão deste artigo obedece aos movimentos de mudança política na América do Sul nestes dois tempos. Primeiramente, será analisada em linhas gerais a ascensão e a queda do neoliberalismo na região. Em seguida, discutir-se-á o perfil de novas lideranças e os condicionantes impostos ao nacionalismo, que emerge com formas e graus muito diversos. E finalmente, antes de chegar às conclusões, será feita uma articulação entre as duas seções anteriores, com uma discussão sobre as conseqüências populistas do institucionalismo periférico, uma variante da ação liberal fora do centro.

\section{ASCENSÃO E QUEDA DO NEOLIBERALIS- $\mathrm{MO}$}

A crise do Estado, diagnosticada nos anos 1980 e cuja natureza fiscal esteve muito fortemente relacionada ao crescimento da dívida pública e às dificuldades de manter o padrão de financiamento sustentado nas décadas anteriores, permitiu o estabelecimento de um "consenso" sobre as reformas estruturais necessárias para estabilizar as economias e reconduzi-las a um campo de novas possibilidades, trazidas por outro fenômeno mundial, amplamente conhecido como globalização. Esse "consenso" foi explicitado em seminário em Washington e, desde então, passou a compor a agenda central de proposições dos principais organismos econômicos internacionais, a exemplo do Banco Mundial e do Fundo Monetário Internacional (FMI) ${ }^{4}$.

A agenda de reformas proposta e logo colocada em prática por toda a América Latina era essencialmente liberal, isto é, dirigia-se ao mercado segundo uma perspectiva de redução do papel do Estado na economia. De maneira geral, ocorreram por toda a região uma onda de privatizações, choques de abertura comercial, desregulamentação e todo tipo a mais de ajuste imbuído do mesmo espírito. Em alguns países houve ainda reformas que flexibilizavam a legislação trabalhista, alteravam as regras previdenciárias e mexiam com a máquina estatal e os servidores públicos.

Após algumas tentativas malsucedidas, a inflação foi finalmente controlada. No final da década de 1990, esse problema já não assustava tanto os países sul-americanos como no início da década. No entanto, as bases dessa estabilização monetária mantinham-se frágeis na medida em que o processo de endividamento continuou e as economias ficaram ainda mais vulneráveis às mudanças de humor no cenário internacional. A situação fiscal permanecia preocupante porque mesmo com cargas tributárias elevadas e anos de políticas ortodoxas austeras e forte ajustamento, o Estado não conseguia financiar suficientemente as políticas de reversão do quadro social, investindo mais em infra-estrutura ou em educação e saúde.

QUADRO 1 - ÍNDICE DE ESTABILIDADE POLÍTICA (IEP)

\begin{tabular}{|c|}
\hline $\begin{array}{c}\text { IEP }=(\mathrm{NE}-\mathrm{NC}) / \mathrm{NT} \\
\text { Em que: }\end{array}$ \\
\hline $\begin{array}{c}\mathrm{NC}=\text { número de semestres registrados por } \\
\text { indicadores }\end{array}$ \\
\hline NE = número de semestres nẫo registrados \\
\hline NT = número total de semestres \\
\hline $\begin{array}{l}\text { Variaçẫo do índice: }-1,0 \text { (menos estável) a 1,0 } \\
\text { (mais estável) }\end{array}$ \\
\hline
\end{tabular}

4 Dezenas de livros, artigos e documentos foram publicados desde o final dos anos 1980 que, de uma forma ou de outra, e em graus variados, reproduziram idéias relacionadas ao consenso de Washington. Nesse sentido, vale conferir, por exemplo, Haggard e Kaufman (1995), Naím (1995),
Diamond e Platter (1996), entre muitos outros, incluindo a literatura brasileira especializada. Vale a pena ver também os textos produzidos pelo Banco Mundial e o FMI ao longo desse período e verificar as mudanças ocorridas 20 anos depois. 


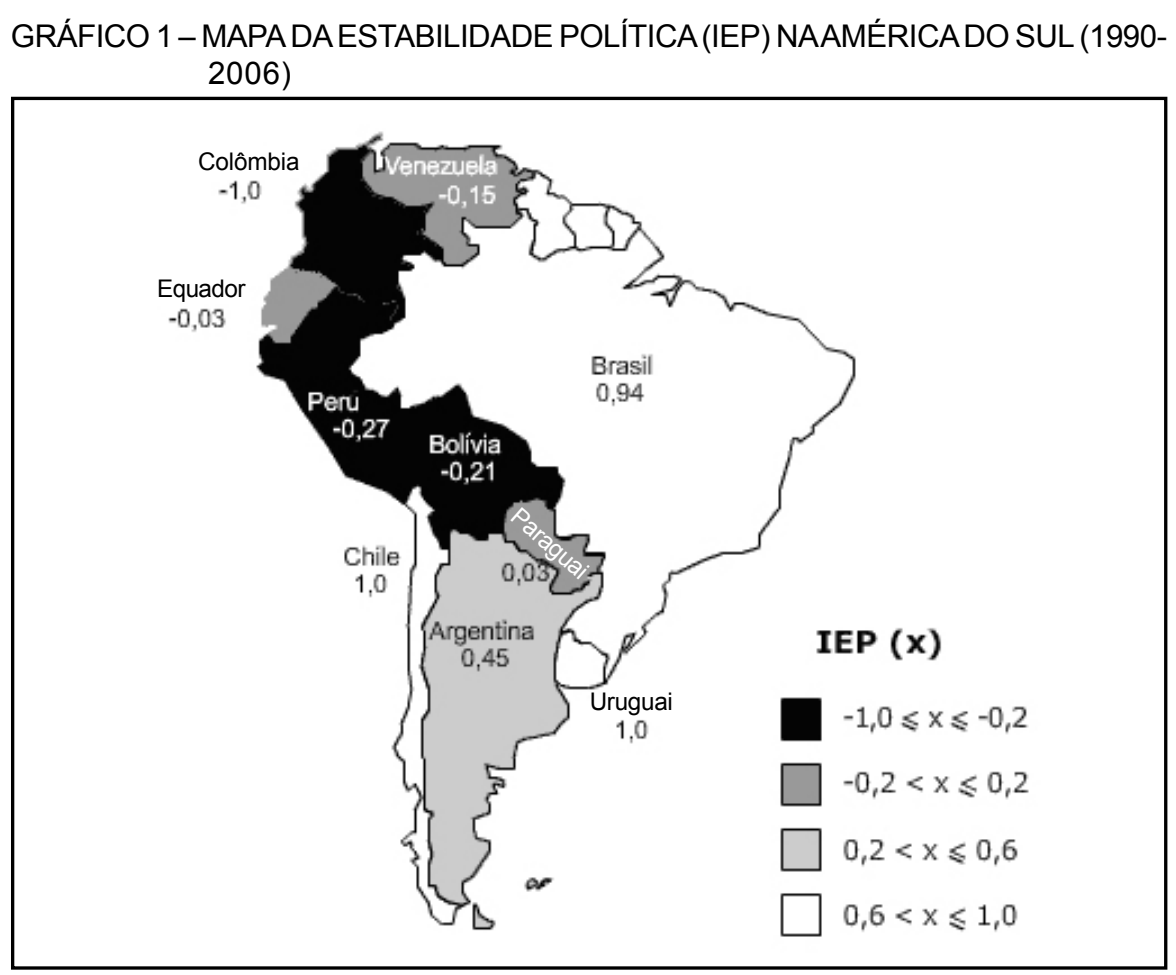

FONTE: Observatório Político Sul-Americano (OPSA).

Durante anos consolidou-se uma visão segundo a qual era preciso redefinir as atribuições do Estado nacional preparando-o para uma nova ordem econômica global já em andamento e que, cedo ou tarde, forçaria todos os países a caminharem numa mesma direção: a das democracias de livre mercado, mais abertas aos fluxos comer- cias e de investimento. Apenas dessa forma é que os países, principalmente aqueles cujos Estados estivessem com grandes dificuldades financeiras, encontrariam um meio apropriado e moderno de financiar o seu desenvolvimento. Os que mais prontamente se inserissem a essa nova ordem, mais rápido também dela tirariam proveito.

\section{GRÁFICO 2 - ESTABILIDADE POLÍTICA (IEP) NAAMÉRICA DO SUL (1994-2006)}

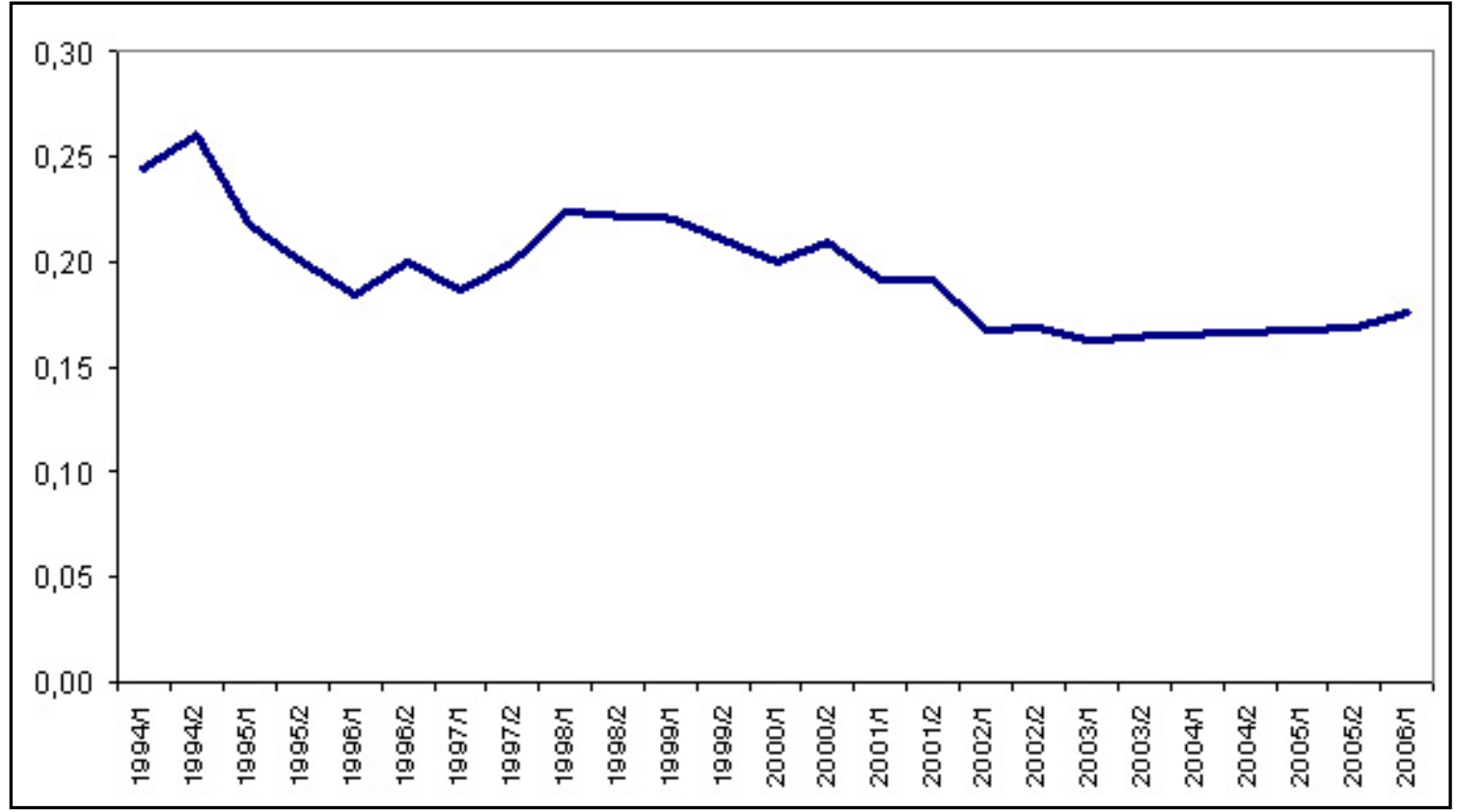

FONTE: Observatório Político Sul-Americano (OPSA). 
O raciocínio de que a salvação viria de fora, por intermédio de novos investimentos externos, da compra de empresas estatais e de títulos públicos por grande players internacionais e de um incremento no comércio com outros países, em particular os Estados Unidos e a Europa, conseguiu prosperar porque, após algumas décadas, entrou em colapso o antigo modelo nacional de desenvolvimento, baseado na substituição de importações e no fomento do mercado interno, com forte presença do Estado. Além disso, independentemente de como ela seja definida, a globalização avançava a passos largos, tornando obsoletas as economias mais fechadas.
O limite da ideologia liberal em voga nas últimas décadas do século XX foi mesmo prever o desaparecimento do próprio Estado, ou pelo menos a redução dramática de sua importância visà-vis uma suposta disfuncionalidade ou inaptidão estatal em um mundo cada vez mais interdependente e onde as fronteiras territoriais perderiam qualquer significado. A crença no fim da história e no caminho inexorável para um modelo de democracia representativa ocidental também compôs esse acervo ideológico em que se encaixavam perfeitamente as reformas direcionadas ao mercado, posteriormente batizadas com o nome de neoliberalismo ${ }^{5}$

GRÁFICO 3 - ESTABILIDADE POLÍTICA (IEP) NOS PAÍSES ANDINOS (1994-2006)

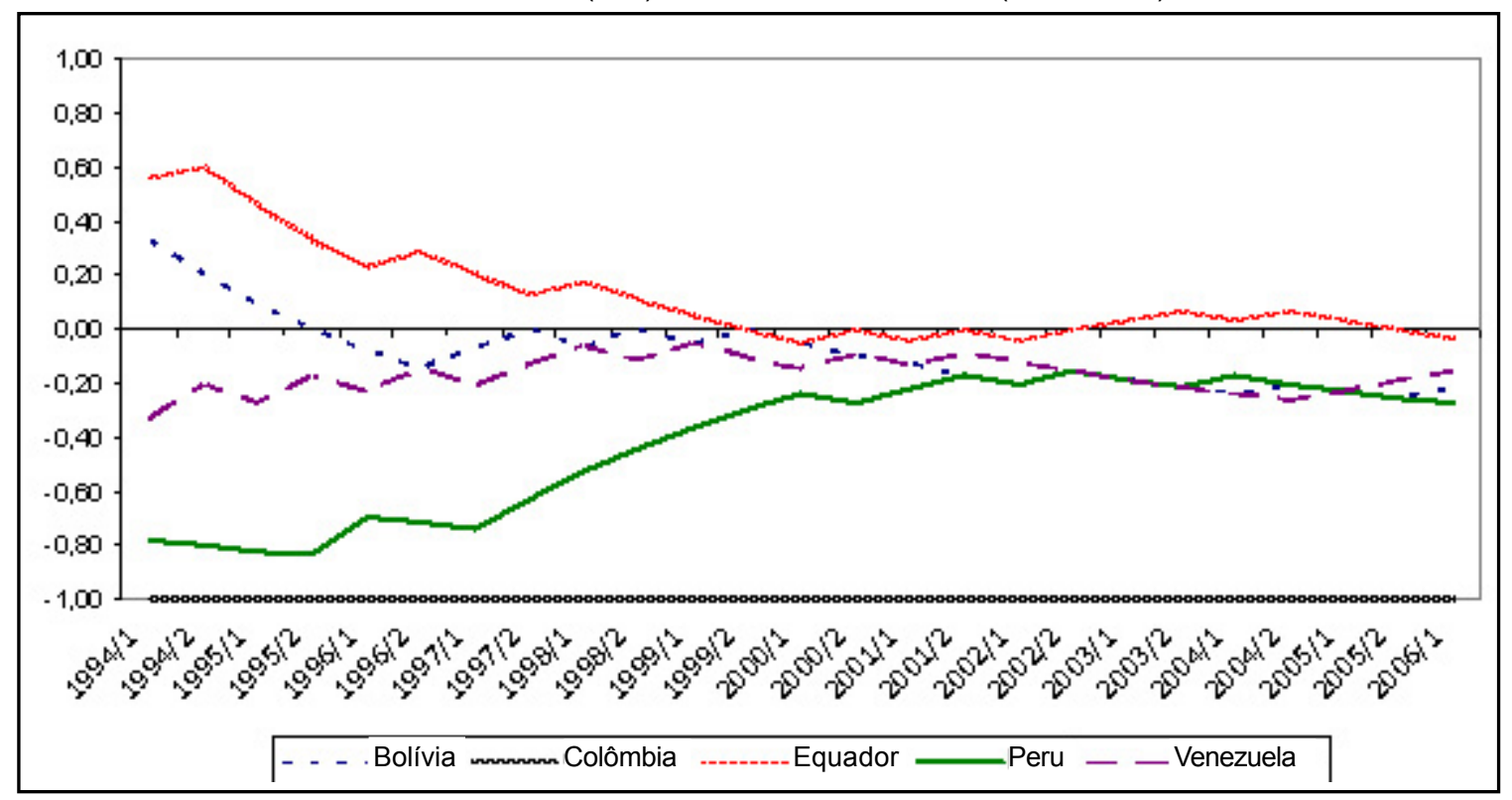

FONTE: Observatório Político Sul-Americano (OPSA).

\footnotetext{
5 No campo das Relações Internacionais, a crença na supressão ou perda relativa de importância do Estado foi amplamente difundida por correntes teóricas liberais abrigadas no funcionalismo, no construtivismo ou mesmo entre vertentes pós-modernas (CRAWFORD, 1996; AXTMANN, 1997; LATHAM, 1997). Especificamente sobre a inexorabilidade da democracia liberal e a terceira onda de democratização, ler Fukuyama (1992) e Huntington (1994).
} 
GRÁFICO 4 - ESTABILIDADE POLÍTICA (IEP) NO CONE SUL (1994-2006)

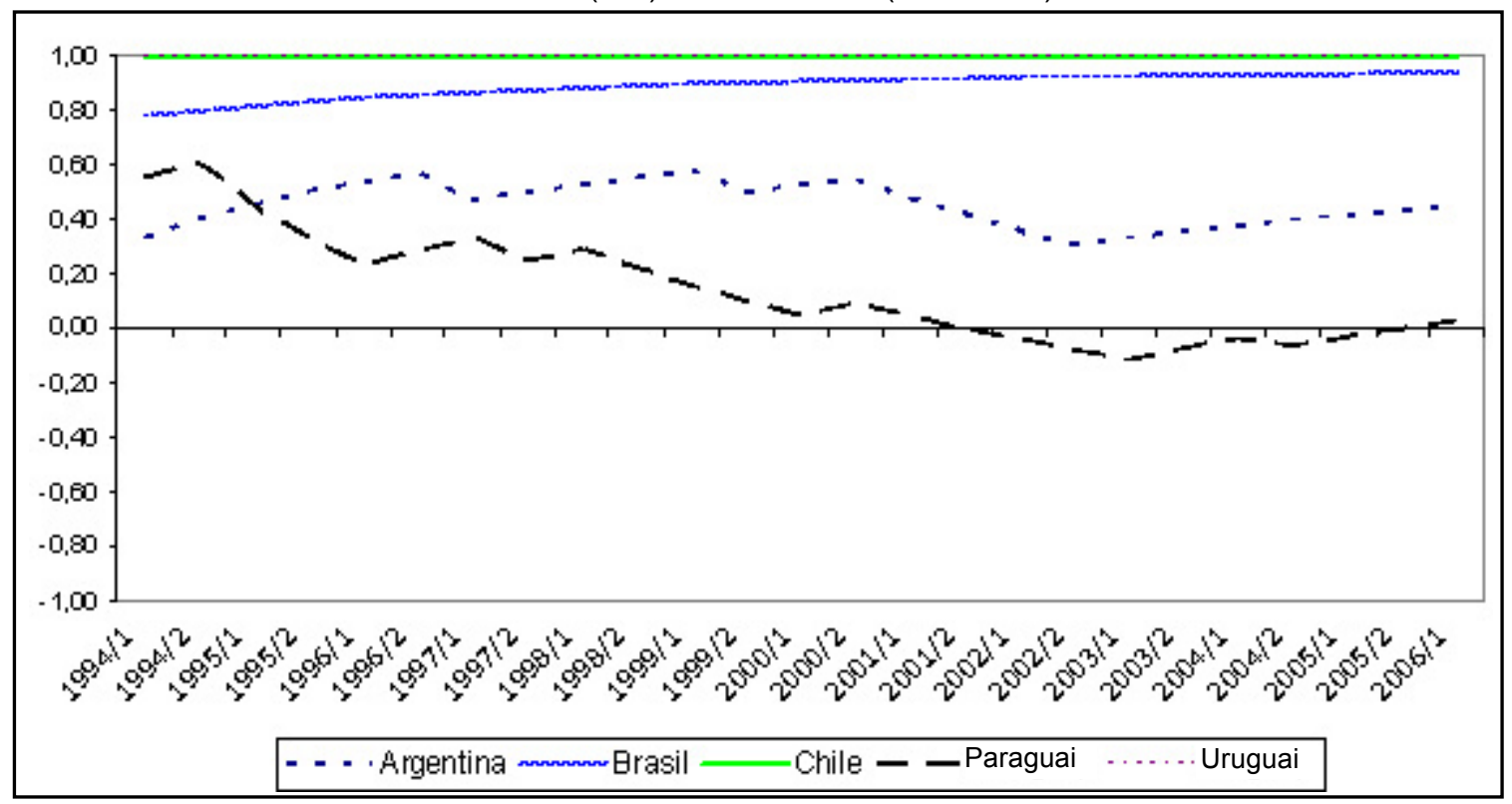

FONTE: Observatório Político Sul-Americano (OPSA)

O pensamento neoliberal transformou-se em práticas e políticas hegemônicas nos anos 1990 pelas mãos de novas lideranças e coalizões governamentais de centro-direita: Carlos Menem, na Argentina, pela ala mais à direita do Partido Justicialista (PJ, 1990-2000); na Bolívia, Gonzalo Sanches de Lozada (MNR, 1993-1997 e 2002-2003) e Hugo Banzer Soarez (ADN, 1997-2001); os presidentes brasileiros eleitos Fernando Collor (PRN, 19901992) e Fernando Henrique Cardoso (PSDB, 19942002), ambos apoiados pelo PFL; na Colômbia, Cézar Gaviria Trujillo (PLC, 1990-1994), Ernesto Samper Pizano (PLC, 1994-1998), Andrés Pastrana
Arango (PSC, 1998-2002) e Álvaro Uribe (Primeiro Colômbia, 2002-2006); no Equador, os presidentes eleitos Durán Ballén (PUC, 1992-1996), Abdalá Bucaram (PRE, 1996-1997) e Jamil Mahuad (DP, 1998-2002); No Paraguai, os presidentes da ANR, Juan Carlos Monti (1993-1998), Raúl Cubas Grau (1998-1999) e Luis Gonzáles Macchi (19992003); no Peru, Alberto Fujimori (C90, 1990-2000); no Uruguai, Luis Alberto Localle (PN, 1989-2004), Julio Maria Sanguinetti (PC, 1994-1999) e Jorge Batle (PC, 1999-2004), e, finalmente, na Venezuela, Carlos Andrés Pérez (AD, 1988-1993) e Rafael Caldera (CN, 1993-1998)

TABELA 1 - VIOLÊNCIAPOLÍTICA POR ÁREA (FEV.-MAR.2006)

\begin{tabular}{|c|c|c|c|c|c|}
\hline \multirow{2}{*}{ PAís } & \multicolumn{2}{|c|}{ CAPITAIS } & \multicolumn{2}{c|}{ INTERIOR } & \multirow{2}{*}{ TOTAL } \\
\cline { 2 - 5 } & $N$ & $\%$ & $N$. & $\%$ & 149 \\
\hline A.rgentina & 56 & $37,6 \%$ & 93 & $62,4 \%$ & 109 \\
Bolívia & 36 & $33,0 \%$ & 73 & $67,0 \%$ & 73 \\
Brasil & 50 & $68,5 \%$ & 23 & $31,5 \%$ & 0 \\
Chile & 0 & - & 0 & - & 1163 \\
Colômbia & 78 & $6,7 \%$ & 1085 & $93,3 \%$ & 509 \\
Equador & 367 & $72,1 \%$ & 142 & $27,9 \%$ & 12 \\
Paraguai & 0 & $0,0 \%$ & 12 & $100,0 \%$ & 94 \\
Peru & 0 & $0,0 \%$ & 94 & $100,0 \%$ & 23 \\
Uruguai & 13 & $56,5 \%$ & 10 & $43,5 \%$ & 33 \\
Venezuela & 14 & $42,4 \%$ & 19 & $57,6 \%$ & 2165 \\
Total & 614 & $28,4 \%$ & 1551 & $71,6 \%$ & \\
\hline
\end{tabular}

FONTE: Observatório Político Sul-Americano (OPSA). NOTA: não inclui os meses de janeiro de 2005 e de 2006.

$\overline{6}$ O caso chileno é excepcional no continente porque adodisso, embora tenha adotado medidas extremas como a privatização da previdência, conjugou a liberalização da economia com a proteção de setores considerados estratégicos no país, sobretudo na área de recursos naturais e fluxo de capital. tou uma agenda bastante precoce de reformas de mercado, iniciada já nos anos 1970 e no período autoritário. Além 
Todas essas lideranças do período neoliberal acreditavam que implementando a agenda de reformas condicionada pelas organizações econômicas internacionais com inspiração inequívoca em modelos de outros países, em particular a Inglaterra de Margareth Thatcher e os Estados Unidos de Ronald Reagan, conseguiriam retirar suas nações do atoleiro fiscal e conduzi-las a um novo patamar de desenvolvimento. A mentalidade da época era a de que a associação com o mercado internacional deveria acontecer de qualquer maneira, por princípio, mesmo sob o sacrifício de setores industriais incipientes. Na realidade, imaginava-se que a liberalização modernizaria a economia nacional, tornando-a mais competitiva. $\mathrm{O}$ que se viu na prática, contudo, foi a manutenção de economias primário-exportadoras deficitárias e o desmantelamento da indústria local. Apenas o Brasil apresentou alguns casos de sucesso nessa área, com forte adaptação competitiva, apesar do câmbio sobrevalorizado. Na Argentina houve quase uma total desindustrialização do país devida, entre outros motivos, ao atrelamento de sua moeda ao dólar.

TABELA 2 - VIOLÊNCIA POLÍTICA POR TIPO DE VÍTIMA(FEV.2005-MAR.2006)

\begin{tabular}{|c|c|c|c|c|c|c|c|c|c|}
\hline \multirow[t]{2}{*}{ PAÍS } & \multicolumn{2}{|c|}{$\begin{array}{l}\text { FORÇAS DE } \\
\text { SEGURANÇA }\end{array}$} & \multicolumn{2}{|c|}{$\begin{array}{c}\text { GRUPOS } \\
\text { ARMADOS } \\
\text { ORG ANIZADOS }\end{array}$} & \multicolumn{2}{|c|}{ CIVIS } & \multicolumn{2}{|c|}{ INCERTO } & \multirow[t]{2}{*}{ TOTAL } \\
\hline & $N$. & $\%$ & $N$ & $\%$ & $N$. & $\%$ & $N$. & $\%$ & \\
\hline $\begin{array}{l}\text { Argentina } \\
\text { Bolivia } \\
\text { Brasil }\end{array}$ & $\begin{array}{l}61 \\
34 \\
27\end{array}$ & $\begin{array}{l}40,9 \% \\
31,2 \% \\
37,0 \%\end{array}$ & $\begin{array}{l}0 \\
8 \\
0\end{array}$ & $\begin{array}{l}0,0 \% \\
7,3 \% \\
0,0 \%\end{array}$ & $\begin{array}{l}88 \\
67 \\
46\end{array}$ & $\begin{array}{l}59,1 \% \\
61,5 \% \\
63,0 \%\end{array}$ & $\begin{array}{l}0 \\
0 \\
0\end{array}$ & $\begin{array}{l}0,0 \% \\
0,0 \% \\
0,0 \%\end{array}$ & $\begin{array}{c}149 \\
109 \\
73\end{array}$ \\
\hline Chile & 0 & - & 0 & - & 0 & - & 0 & - & 0 \\
\hline Colômbia & 390 & $33,5 \%$ & 328 & $28,2 \%$ & 385 & $33,1 \%$ & 60 & $5,2 \%$ & 1163 \\
\hline Equador & 6 & $1,2 \%$ & 0 & $0,0 \%$ & 447 & $87,8 \%$ & 56 & $11,0 \%$ & 509 \\
\hline Paraguai & 1 & $8,3 \%$ & 0 & $0,0 \%$ & 11 & $91,7 \%$ & 0 & $0,0 \%$ & 12 \\
\hline Perú & 13 & $13,8 \%$ & 1 & $1,1 \%$ & 60 & $63,8 \%$ & 20 & $21,3 \%$ & 94 \\
\hline Uruguai & 10 & $43,5 \%$ & 0 & $0,0 \%$ & 13 & $56,5 \%$ & 0 & $0,0 \%$ & 23 \\
\hline Venez uela & 0 & $0,0 \%$ & 0 & $0,0 \%$ & 33 & $100,0 \%$ & 0 & $0,0 \%$ & 33 \\
\hline Total & 542 & $25,0 \%$ & 337 & $15,6 \%$ & 1150 & $53,1 \%$ & 136 & $6,3 \%$ & 2165 \\
\hline
\end{tabular}

FONTE: Observatório Político Sul-Americano (OPSA).

NOTA: não inclui os meses de janeiro de 2005 e 2006.

Após mais de uma década de reformas estruturais, excetuando-se a inflação, o contexto sul-americano não se havia modificado muito. $\mathrm{O}$ que se esperava e o que foi prometido pelo consenso de Washington simplesmente não foram alcançados. Os Estados continuaram enfrentando graves problemas fiscais. Na maior parte dos países, a relação dívida/produto interno bruto superou $50 \%$ e, em alguns casos, como no Uruguai, essa relação dramatizou-se ainda mais, com o comprometimento de mais de $90 \%$ da riqueza produzida no país com o endividamento (COUTINHO, 2006; LIMA \& COUTINHO, 2006). AAmérica do Sul habituou-se à idéia de ajustes e de contingenciamento sem, com isso, conseguir avançar mais significativamente em seus objetivos, pois o Estado continuava debilitado a despeito de todos os esforços empreendidos.

Na década neoliberal, o crescimento econômico médio continuou baixo e oscilante, mesmo para os padrões latino-americanos. O desemprego, a informalidade e a desigualdade social aumentaram. E a pobreza reduziu marginalmente. O quadro, por- tanto, permaneceu praticamente inalterado do ponto de vista estrutural. Por sua vez, se a economia conseguiu ao menos estabilizar-se com o controle de preços, o mesmo não é possível dizer sobre a política e as instituições democráticas. Embora os processos eleitorais tenham-se normalizado na América do Sul e - salvo a exceção peruana de Fujimori - não tenha havido a volta de regimes autoritários, as crises institucionais continuaram bastante recorrentes (cf. gráficos 1 e 2). A região andina foi a mais problemática, porém crises importantes também atingiram países do Cone Sul, sobretudo o Paraguai e, em seguida, a Argentina. A instabilidade política diminuiu de maneira sustentável apenas no Brasil, que se nivelou ao índice do Chile e do Uruguai (cf. gráficos 3 e 4) ${ }^{7}$.

\footnotetext{
7 Para maiores detalhes sobre o índice de instabilidade política, ler Coutinho (2005). Informações sobre esse índice e dados sobre violência política podem também ser encontrados no sítio eletrônico do Observatório Político SulAmericano: http://observatorio.iuperj.br.
} 
TABELA 3 - VIOLÊNCIA POLÍTICA POR OCORRÊNCIA(FEV.2005-MAR.2006)

\begin{tabular}{|c|c|c|c|c|c|c|c|}
\hline \multirow{2}{*}{ PAís } & \multicolumn{2}{|c|}{ MORTOS } & \multicolumn{2}{c|}{ FERIDOS } & \multicolumn{2}{c|}{$\begin{array}{c}\text { SEQÜESTRADOS } \\
\text { DESAPARECIDOS }\end{array}$} & \multirow{2}{*}{ TOTAL } \\
\cline { 2 - 7 } & $N$. & $\%$ & $N$ & $\%$ & $N$. & $\%$ & \\
\hline Argentina & 2 & $1,3 \%$ & 147 & $98,7 \%$ & 0 & $0,0 \%$ & 149 \\
Bolívia & 10 & $9,2 \%$ & 89 & $81,7 \%$ & 10 & $9,2 \%$ & 109 \\
Erasil & 2 & $2,7 \%$ & 63 & $86,3 \%$ & 8 & $11,0 \%$ & 73 \\
Chile & 0 & - & 0 & - & 0 & - & 0 \\
Colômbia & 733 & $63,0 \%$ & 362 & $31,1 \%$ & 68 & $5,8 \%$ & 1163 \\
Equador & 2 & $0,4 \%$ & 507 & $99,6 \%$ & 0 & $0,0 \%$ & 509 \\
Paraguai & 9 & $75,0 \%$ & 3 & $25,0 \%$ & 0 & $0,0 \%$ & 12 \\
Peru & 14 & $14,9 \%$ & 78 & $83,0 \%$ & 2 & $2,1 \%$ & 94 \\
Uruguai & 0 & $0,0 \%$ & 23 & $100,0 \%$ & 0 & $0,0 \%$ & 23 \\
Venezuela & 6 & $18,2 \%$ & 27 & $81,8 \%$ & 0 & $0,0 \%$ & 33 \\
Total & 778 & $35,9 \%$ & 1299 & $60,0 \%$ & 88 & $4,1 \%$ & 2165 \\
\hline
\end{tabular}

FONTE: Observatório Político Sul-Americano (OPSA).

NOTA: não inclui os meses de janeiro de 2005 e 2006.

Ao contrário do que se imaginava tampouco a violência política extinguiu-se com as transições para a democracia (cf. tabelas 1 a 3 e gráficos 5 e 6). Ainda que os índices de violência com essa natureza tenham declinado sensivelmente quando comparados aos dos regimes militares - por exemplo, na Argentina e no Chile, durante os anos 1970 -, eles continuaram elevados nos anos 1990 e 2000. Um levantamento inicial dessa violência indica que, mesmo após 25 anos de democratização, mais de duas mil pessoas foram mortas $(36 \%)$, feridas $(60 \%)$, desaparecidas ou seqüestradas (4\%), no período de um ano, entre 2005 e 2006. Essa violência aconteceu mais no interior dos países $(71,6 \%)$ do que nas capitais $(28,4 \%)$, e atingiu, em sua maioria, civis $(53,1 \%)$, seguidos das forças de segurança $(25 \%)$ e de grupos armados $(15,6 \%)$. Os países mais politicamente violentos em termos proporcionais foram o Equador e a Colômbia. A violência neste último, provocada pela guerra interna, levou a morte de pelo menos 733 pessoas, entre fevereiro de 2005 a março de 2006, segundo dados levantados nos principais jornais do país. Por outro lado, aqueles que apresentaram os índices mais baixos de violência foram o Chile e o Brasil, o que reforça a tese de que sejam, de fato, os países mais estáveis da região.

GRÁFICO 5 - VIOLÊNCIA POLÍTICA POR MÊS (FEV.2005-MAR.2006)

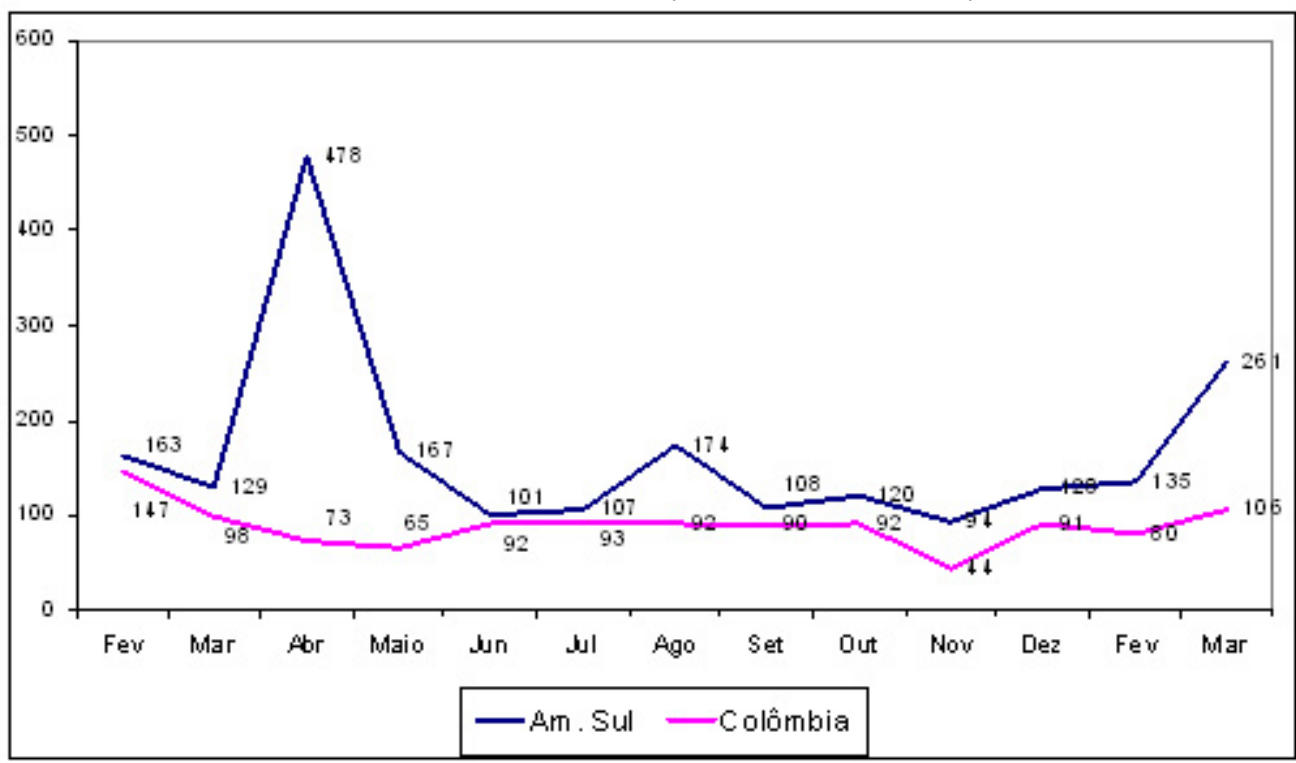

FONTE: Observatório Político Sul-Americano (OPSA).

NOTA: não inclui os meses de janeiro de 2005 e 2006. 
GRÁFICO 6 - MAPA DA VIOLÊNCIA POLÍTICANAAMÉRICA DO SUL (FEV.2005-MAR.2006)

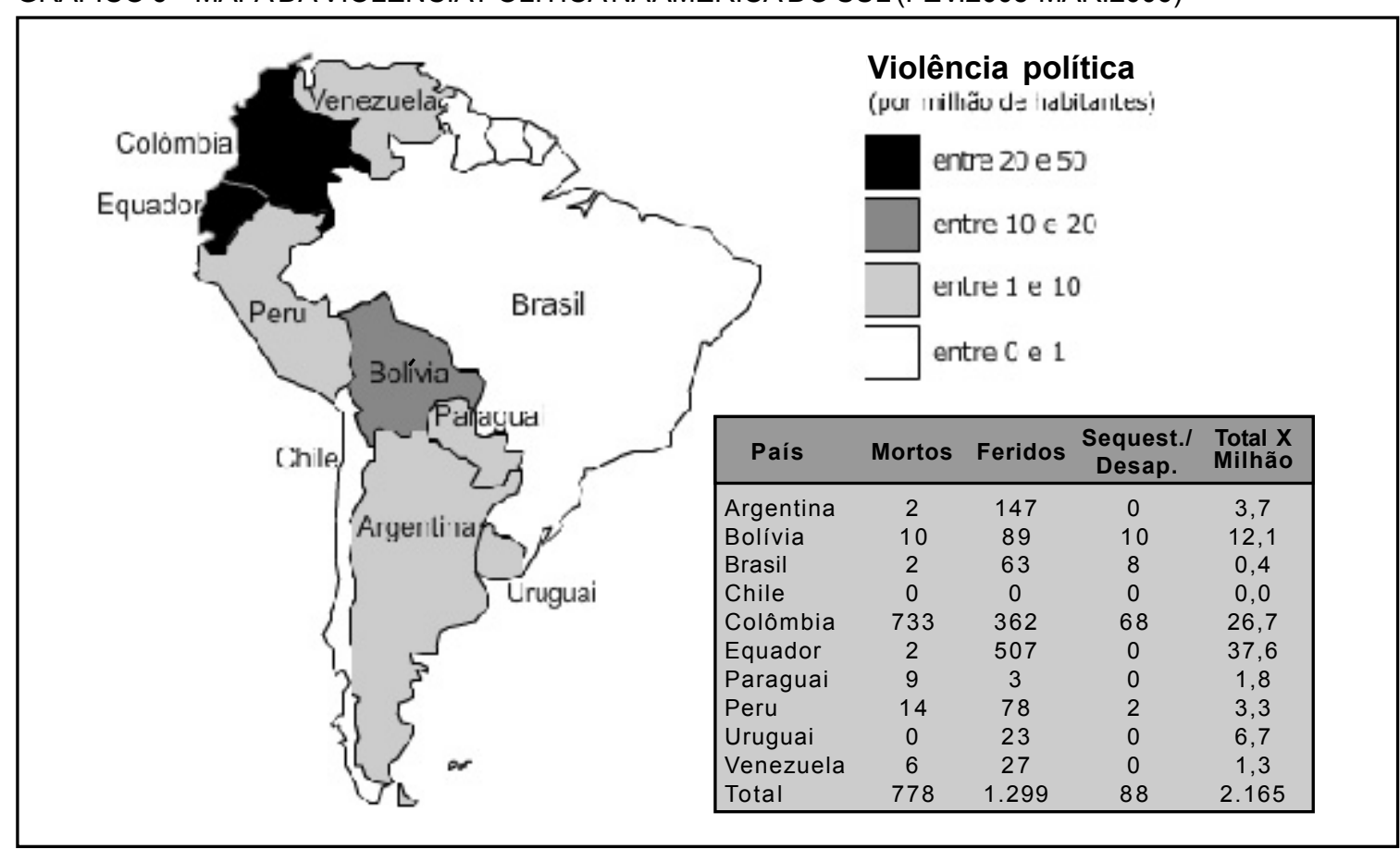

FONTE: Observatório Político Sul-Americano (OPSA).

NOTA: não inclui os meses de janeiro de 2005 e 2006.

É importante notar que as razões do declínio do neoliberalismo na América do Sul na primeira metade dos anos 2000 residem, em boa parte, nos próprios motivos que levaram ao seu aparecimento. Na realidade, essa constatação sobre as fragilidades internas da ascensão e queda do liberalismo econômico já havia ocorrido para o caso norteamericano décadas antes: "Understanding where postwar liberalism came from is part of understanding where it has gone, and why"8 (BRINKLEY, 1998, p. xi). No entanto, em nenhum desses dois momentos do liberalismo nas Américas, o consenso formado em torno do "bom governo" correspondeu às respectivas realidades nacionais. A possibilidade latino-americana de um período pós-neoliberalismo ou pós-hegemônico abriu-se, portanto, quando as fragilidades do modelo liberal vigente, que nunca chegou a ser concretamente de desenvolvimento, tornaram-se visíveis e ainda mais incongruentes com uma região em franco processo democrático e que ainda

8 "Entender de onde o liberalismo do período do pósguerra veio é parte do entendimento de aonde ele foi e porquê" (tradução livre do editor). precisava resolver problemas sociais e políticos básicos, como a incorporação de novos atores e uma mínima condição de bem estar e igualdade.

\section{NOVOS LÍDERES E O NACIONALISMO EMERGENTE}

Uma observação apressada poderia concluir que, ao contrário da sua primeira manifestação entre os séculos XIX e XX, a versão contemporânea do liberalismo econômico teve fôlego relativamente curto. Isso seria potencialmente verdade caso as reformas já tivessem de fato chegado ao fim, e que uma outra agenda de políticas fosse colocada em seu lugar. Mas nada na América do Sul permite ainda assegurar que o declínio do neoliberalismo represente mudanças drásticas de fundamento em toda a região. O que se verificou entre 1999 e 2006 é o esgotamento do modelo liberal na maioria dos países, com a manutenção de velhos problemas, incluindo a questão fiscal e o desafio da inserção no mundo globalizado. Desse modo, o fato de o neoliberalismo ter fracassado em termos de resultados não retira as reformas do horizonte dos países da América do Sul e muito menos significa que o nacionalismo emergente possa ser aplicado igualmente em todos os 
casos, ou mesmo que ele consiga estabelecer-se a exemplo dos anos de maior desenvolvimento9.

Examinando todos os casos, observa-se a existência de uma variedade expressiva de continuidade e mudança entre os países da região. Em alguns países, como a Argentina, a mudança de fundamentos da política econômica é bastante clara. Em outros, como o Brasil, a dose de continuidade da ortodoxia é maior. Na Bolívia e na Venezuela, a revisão generalizada de políticas adotadas no período neoliberal, como a privatização, é bem nítida. Já na Colômbia persiste a mesma doutrina liberal. Sendo assim, embora sua força seja inegável, a guinada à esquerda e mais nacionalista que atinge a região na virada de século está muito longe de ser uniforme ou representar o fim completo da liberalização econômica no continente. No geral, ela está mais para um acerto de contas e de rumos pós-euforia liberal do que para uma ruptura definitiva que consiga sobrepor-se ou mesmo ignorar o movimento de internacionalização, há décadas em curso, de maneira mais acelerada.

Decepcionadas com as reformas estruturais e com o desempenho social da democracia, as populações em quase todo o continente restauraram suas esperanças elegendo novos líderes e conduzindo ao poder forças políticas aparentemente mais preocupadas com a defesa dos interesses nacionais e com questões referentes à pobreza e à desigualdade, segundo o escrutínio dos próprios eleitores (COUTINHO, 2006; LIMA \& COUTINHO, 2006b). A lista de novos presidentes é grande: Hugo Chávez (Venezuela, 1998); Ricardo Lagos (Chile, 1999); Lula (Brasil, 2002); Nestor Kirchner (Argentina, 2003); Tabaré Vázquez (Uruguai, 2004); Evo Morales (Bolívia, 2005); Michelle Bachelet (Chile, 2006); e Alan Garcia (Peru, 2006). Mesmo na Colômbia, com a vitória do conservador Álvaro Uribe, a esquerda nunca obteve resultados

9 Uma das principais diferenças entre o desenvolvimentismo predominante entre as décadas de 1940 e 1970 e o neodesenvolvimentismo em gestação nos anos 2000 é que, uma vez situado em um contexto mais democrático, este último dá mais ênfase ao problema da desigualdade social, algo secundário ou mesmo fora das preocupações no passado da região. Dessa forma, seria mais importante "dividir o bolo" para crescer do que o contrário. Outras diferenças são a maior abertura ao comércio global e a prioridade adquirida pela integração sul-americana, escapando-se, com isso, de um modelo centrado apenas nos limites nacionais. eleitorais tão expressivos como em 2006, com o Pólo Democrático Alternativo (PDA).

Nota-se que as lideranças emergentes vão aos poucos constituindo uma onda de mudança política bastante diversificada, mas, de maneira geral, no sentido contrário ao da década anterior ${ }^{10}$. São anos que apresentam um grande dinamismo político e, em muitos casos, uma fase também de experimentação. Uma breve análise deve constatar a existência de presidentes das mais diversas origens sócio-econômicas, profissionais e políticas. Muitos deles, inclusive, com uma boa vivência internacional na Europa e nos Estados Unidos. Existem representantes genuínos dos setores indígena e operário (Morales e Lula) e um ex-militar (Chávez). Porém, a maioria continua mesmo a advir das elites e classes médias: dois médicos (Tabaré e Bachelet, a única mulher na Presidência) e três advogados (Kirchner, Garcia e Uribe: os dois últimos também cientistas políticos).

Embora todos ou quase todos confluam para uma posição crítica das políticas implementadas pelos governos antecessores, as trajetórias políticas dessas novas lideranças e dos movimentos que representam também são muito específicas ${ }^{11}$. Alguns chegaram ao poder após um longo processo de convencimento da sociedade e, mesmo, depois de sucessivas tentativas eleitorais, como no caso de Lula, com o Partido dos Trabalhadores (PT) e de Vázquez, com a sua Frente Ampla. Outros ascenderam mais rapidamente como Morales e Kirchner. Sobre essa questão é importante perceber que, enquanto as lideranças do Cone

10 Provavelmente, a melhor forma de reconhecer a nova onda política na região é pela derrota da centro-direita, que, em 2006, governa apenas a Colômbia e o Paraguai. Todos os demais países da América do Sul (Brasil, Argentina, Chile, Uruguai, Bolívia, Equador, Peru e Venezuela) são governados nesse período por forças e representantes de outros círculos ideológicos, ainda que haja continuidade nas políticas implementadas. Há, portanto, um quadro inverso àquele observado ao longo dos anos 1990.

11 Mais uma vez é importante ressaltar o caso chileno como uma exceção entre os governos de esquerda, pois, mesmo sendo Lagos e Bachelet membros do Partido Socialista (PS) e tendo eles introduzido mudanças importantes - principalmente esta última com, por exemplo, uma reforma previdenciária mais inclusiva - ambos pertencem à coalizão de governo que comanda o país desde a transição para a democracia e também são responsáveis, portanto, pelas políticas adotadas. 
Sul consolidaram posições partidárias para alcançar o poder, nos Andes os partidos políticos foram simplesmente suplantados pelos novos movimentos; salvo o Partido Aprista, de Alan Garcia, que consegue depois retornar à cena política adotando, ao menos inicialmente, uma postura bem mais moderada e que guarda grandes afinidades com o modelo chileno, tal qual seu antecessor Alejandro Toledo.

Ainda que Morales possa ser mais radical e estar ideologicamente mais próximo a Chávez, as origens sindicais do presidente do Movimento ao Socialismo (MAS) e sua iniciativa de institucionalizar um movimento político o aproximam mais do presidente petista. $\mathrm{O}$ presidente venezuelano apresenta uma postura mais personalista se comparado às outras lideranças regionais. Mesmo gozando de grande apelo popular, Lula e Morales governam fazendo mais um jogo institucional do que de mobilização social. Lula, sobretudo, faz menos uso de sua força popular nas relações que estabelece com o Congresso e com setores organizados da sociedade, preferindo reproduzir uma lógica de alianças e de compromissos mais diversificada e por dentro do sistema político já existente. Morales, por sua vez, embora represente um período de transformações profundas no sistema partidário (em geral semelhante aos dos demais países andinos) e lance mão dos movimentos sociais que o apóiam, constrói também um sistema de relações políticas mais institucionalizado do que o de Chávez. Uma prova disso é a forma de atuação do MAS e da própria oposição, principalmente na figura do Poder Democrático e Social (Podemos), que é um partido mais forte e mais organizado do que qualquer partido opositor presente na Venezuela durante esse período.

O personalismo, todavia, não é exclusividade de um tipo de liderança de esquerda. O direitista Álvaro Uribe também ergueu ao longo de seus quatro anos de mandato um sistema muito centrado em sua pessoa. Na Colômbia, os partidos tradicionais igualmente enfraqueceram-se muito e deixaram o palco central da arena política, dando lugar a movimentos independentes, porém, de tendências mais conservadoras. $\mathrm{O}$ apelo às "grandes massas" e uma relação direta com a sociedade é mais visível na Venezuela de Chávez porque o país esteve dividido como jamais esteve nos últimos 40 anos de história política e porque o novo presidente, no caso, enfrentava a oposição de praticamente toda a elite econômica do país.

Assim como Lula, o Presidente argentino Nestor Kirchner é um caso de liderança carismática combinada com uma estrutura partidária já bastante consolidada, a ponto de ser considerado o último dos peronistas ou mesmo a superação desta que, há meio século, compõe a principal tradição política do país. Ao contrário do PT, no entanto, o Partido Justicialista já tem antes desse período uma longa experiência no governo central e se sobressai muito no sistema político que não é tão fragmentado, reunindo facções dos mais diferentes matizes ideológicos, da direita à esquerda. Além disso, Kirchner, que representa os setores mais progressistas do partido, edificou uma enorme liderança no decorrer do mandato presidencial, guardando, do ponto de vista psicológico, algumas afinidades com outro advogado do grupo, o peruano Alan Garcia. Ambos têm um estilo de governo partidarizado, mas ao mesmo tempo muito personificado na figura do presidente $\mathrm{e}$, às vezes, guiado por impulsos intempestivos ou voluntariosos, enquanto Lula exerce uma liderança mais negociadora ${ }^{12}$.

No Uruguai, Tabaré Vázquez está assentado sobre uma base consistente de apoio partidário e desempenha uma liderança de esquerda mais moderada, tal qual Bachelet no Chile que, com sua Concertación, representa o modelo mais sólido e equilibrado de coalizão multipartidária no continente e, exatamente por isso, serve como inspiração política para as novas lideranças de países vizinhos. A ascensão do líder da Frente Ampla lembrou bastante a de Lula, sendo também uma espécie de marco histórico dessa virada à esquerda e da democratização na América do Sul. Essas demonstrações de amadurecimento e estabilidade democrática no Uruguai, no Chile e no Brasil são muito significativas porque ainda contrastam na região com países como o Paraguai de Nicanor

\footnotetext{
12 Enquanto este trabalho é escrito, Alan Garcia preparase para o seu segundo mandato presidencial, não sendo, assim, exatamente uma nova liderança, mas uma liderança renovada. Embora não seja possível ainda fazer uma avaliação segura do que será seu futuro governo, tudo indica que será muito diferente do que foram os seus anos de 1985 a 1989, quando era ainda muito jovem (36 anos) e outra, a circunstância histórica. No segundo mandato, Garcia poderá ser mais moderado e negociador.
} 
Duarte, governado há décadas por um único partido, e o Equador do presidente Alfredo Palácio, que, ao contrário de Duarte, tem tendências esquerdistas. Como foi visto anteriormente, a instabilidade e a violência política equatoriana é uma das mais elevadas. $\mathrm{O}$ último presidente retirado do poder antes de terminar o mandato em 2006 foi Lucio Gutierrez. Gutierrez elegeu-se com uma plataforma de esquerda, mas suas políticas de aprofundamento das reformas de mercado, de aproximação com os setores conservadores e de alinhamento com os Estados Unidos, por intermédio de negociações em torno de um tratado de livre comércio (TLC), o levaram a ser o exemplo mais típico de policy switch (estelionato eleitoral perpetrado pelo neoliberalismo).

Analisados em conjunto, observa-se que essas lideranças emergentes nos primeiros anos do novo século compõem uma geração nascida nas décadas de 1940 e $1950^{13}$. São, portanto, em sua maioria, lideranças relativamente maduras, porém, não obrigatoriamente no fim de suas carreiras políticas. O mais velho desse grupo é Tabaré, com 66 anos, seguido de Lula com 61 anos, e o mais jovem é Morales, com 47 anos. A média de idade de todos os presidentes em exercício em 2006 é de 55 anos. Trata-se, dessa forma, de uma geração que assistiu de perto as ditaduras militares nos anos 1960 e 1970 e participou ativamente dos processos de transição para a democracia nos anos 1980. Não por acaso são também os presidentes que mais claramente buscaram remover o entulho autoritário, principalmente no Chile, Argentina, Uruguai e Peru, promovendo iniciativas como a liberação dos arquivos das ditaduras e esforços no sentido de localizar e identificar desaparecidos, punir culpados e reformar as relações civilmilitares, tornando-as mais compatíveis com os novos regimes democráticos.

Dado o aparecimento de guerrilhas revolucionárias, particularmente na Colômbia e no Peru,

\footnotetext{
13 Ano de nascimento: Tabaré (1940); Lula (1945); Garcia (1949); Kirchner (1950); Bachelet (1951); Uribe (1952); Chávez (1954); Duarte (1956) e Morales (1959). Palácio nasceu em 1939, mas não foi o presidente eleito. Este artigo foi escrito muitos meses antes das eleições presidenciais equatorianas de 2006. Vale notar apenas que o vencedor, Rafael Correa, além de economista, está também mais à esquerda do espectro político em seu país. De 1963, Correa é mais novo do que Morales e o único nascido nos anos 1960 entre essas novas lideranças sul-americanas.
}

alguns líderes vivenciaram uma época de longos conflitos em seus países. Mesmo a Venezuela que não enfrentou um regime militar ou guerrilhas, passou pela revolta conhecida como Caracazo, em 1989, que levou milhares de pessoas à morte e tornou-se também um trauma nacional. Muitas dessas novas lideranças regionais sofreram em família os danos provocados pelo autoritarismo e pelas guerras civis. É o caso de Bachelet, que teve o pai preso e morto no regime de Pinochet, e o de Álvaro Uribe, que teve o pai assassinado pelas Forças Armadas Revolucionárias da Colômbia (FARC), em 1983. Outros foram obrigados a sair do país ou recolher-se a províncias insuladas como no caso de Alan Garcia e Kirchner, respectivamente. Chávez é a prova mais contundente das dificuldades pelas quais passava a democracia venezuelana. Após liderar o golpe de 1992, ainda sobre a memória viva do que foram os movimentos de contestação na década anterior, o rebelde bolivariano é preso, e a partir disso começa a preparar o seu retorno triunfal à cena política alguns anos depois.

$\mathrm{O}$ nacionalismo que emerge no começo do século XXI é uma resposta política ao que foi interpretado como equívoco imposto pela tese neoliberal nas décadas precedentes. No entanto, esta onda nacionalista não é homogênea e nem mesmo chega a configurar-se ainda como um movimento coeso e muito bem definido. Em essência, os anos 2000 marcam o fim do pensamento único, da hegemonia neoliberal, e o início de um período de maior pluralidade e de desdobramentos futuros, em que se encontram diferentes formas democráticas de enfrentar os problemas da liberalização econômica. Isso não implica, certamente, uma volta ao passado isolacionista autárquico ou de maior protecionismo. Mas, por certo, ajuda a unir as sociedades sul-americanas sob novas formas, reorientando políticas para o desenvolvimento e melhores modos de inserção no mundo contemporâneo.

Esse nacionalismo encontra condicionantes que o impedem de transformar-se no que um dia foi o nacional-desenvolvimentismo ou mesmo de apresentar-se com inteireza, independente da forma que assuma. Tais condicionamentos são dados pela expansão do capitalismo na América do Sul e em outros países do mundo, o que acaba gerando dois movimentos paralelos interessantes. Por um lado, observa-se uma recuperação econômica vigorosa na região a partir de 2002, com 
taxas de crescimento e de exportação mais elevadas. Isso sugere a formulação de políticas mais agressivas de conquista internacional de mercados e de incremento da economia doméstica; inclusive com mecanismos de proteção e, em alguns casos, com a revisão das privatizações e a instituição de novos marcos regulatórios, buscando, na medida do possível, reconstruir a capacidade de coordenação e investimento do Estado Nacional, debilitado por décadas de crise fiscal e reformas pró-mercado.

Por outro lado, em compensação, observa-se uma concorrência industrial oriunda de outras economias muito dinâmicas e o protecionismo agrícola em setores em que a América do Sul é bastante competitiva. Isso acarreta aumento das importações de bens manufaturados, gerando uma pressão sobre a economia nacional que não pode ser simplesmente protegida porque, na dose errada, isso levaria também ao esfriamento do expansionismo comercial e do capitalismo doméstico, mesmo sem retaliação externa no setor de commodities, por exemplo. O alargamento da economia dentro e fora da região estabelece laços automáticos e quase indissociáveis, não permitindo, assim, aos países da Américas do Sul isolarem-se sem impor prejuízos ao seu próprio desenvolvimento.

Portanto, o diferencial nessa nova onda política é que a região passa a experimentar formas de conter o ímpeto da liberalização já iniciada, e a tirar vantagens do bom momento mundial, enquanto aproveita para reorganizar a economia; reduzir a dívida pública, a vulnerabilidade externa e os índices de pobreza; restaurar a capacidade infraestrutural; reindustrializar-se e buscar instrumentos próprios de financiamento na região. Como as fórmulas adotadas para lidar com esses desafios são distintas, então, provavelmente os resultados também irão variar caso a caso, conforme as especificidades de cada país. Mas, independente das diferenças individuais, tudo indica uma volta do Estado como indutor do desenvolvimento e o único agente capaz de, em um só tempo, reequilibrar minimamente as tensões existentes entre os mercados e as ruas, e conter o fortalecimento exponencial dos atores externos. Como há limites para a ação isolada do Estado em um mundo cada vez mais globalizado e regionalista, esses países também procuram consolidar um espaço de atuação comum, estabelecendo o que, em tese, representaria um regional-desenvolvimentismo (LIMA \& COUTINHO, 2005).

\section{CONSEQÜÊNCIAS POPULISTAS DO INSTITUCIONALISMO PERIFÉRICO}

Parte significativa dos estudos comparados em América do Sul desde as transições para a democracia nos anos 1980 foi influenciada pela escola institucionalista, ou neo-institucionalista, como é mais conhecida. Em linhas bem gerais, a tese central dessa corrente de interpretação é a de que as instituições - entendidas como sendo as organizações e as regras do jogo, formais ou informais - importam muito ou são mesmo decisivas na determinação do comportamento político (STEINMO, 1992; HALL \& TAYLOR, 1996). Após o enfraquecimento do behaviorismo, a abordagem institucional passa a predominar na Ciência Política norte-americana em diferentes campos, mas na área das Relações Internacionais costuma também assumir o nome das teorias neoliberal e neofuncionalista. Existe uma série de ramificações teóricas nesse sentido. Entre as mais difundidas situam-se o institucionalismo da escolha racional, o institucionalismo sociológico e o institucionalismo histórico, que nos estudos internacionais guarda importantes afinidades com algumas vertentes do construtivismo, nenhuma delas obrigatoriamente alinhada ao liberalismo econômico.

Na política comparada, houve uma grande disseminação de pesquisas sobre formas de governo, sistemas eleitorais e partidários, organização dos legislativos e suas relações com o poder Executivo, entre outros temas. Embora a literatura mundial nunca tenha chegado a uma conclusão definitiva sobre o melhor arranjo institucional para a democracia, havendo sempre grandes discordâncias e diferentes resultados de pesquisas apresentados, na América do Sul dominou uma visão reformista que sugeria a adoção de modelos que, essencialmente, funcionariam bem no mundo desenvolvido, apesar da existência de opiniões dissonantes na própria região (SHUGART \& CAREY, 1992; LAMOUNIER, 1994; MAINWARING \& SCULLY, 1994; SHIN, 1994; HOROWITZ, 1996; LINZ \& STEPAN 1996; LIMA JR., 1997).

Assim como as políticas neoliberais venceram o debate nos anos 1980 e tornaram-se hegemônicas a partir de então, as hipóteses 
institucionalistas para a evolução das democracias sul-americanas também prevaleceram no debate público. A mais importante delas e com conseqüências diretas para a discussão empreendida neste trabalho, é a de que a consolidação das democracias dar-se-ia por intermédio das instituições representativas, as únicas capazes de reproduzirem comportamentos democráticos (a idéia de lock-in é um bom exemplo). Mais do que isso, qualquer iniciativa populista seria automaticamente considerada antidemocrática ou um retrocesso na consolidação do regime, uma vez que conspiraria contra as instituições no intuito de alguns líderes alcançarem uma relação direta com os eleitores, sem intermediação institucional e ao mesmo tempo criarem divisões sociais com potencial para grandes conflitos e crises.

Não obstante as diversas possibilidades de conceituação do populismo, incluindo desde vertentes históricas como as coalizões policlassistas dos anos 1940 e 1950, a definição institucional é a que parece de fato oferecer os melhores rendimentos analíticos. Ela é suficientemente ampla para incluir diferentes tempos e lugares sem ficar obscura ou limitar-se a uma dimensão específica, como em geral ocorre, respectivamente, com o populismo como demagogia carismática e o populismo econômico (WEYLAND, 1996; LODOLA, 2004). De toda forma, parece claro neste conceito, que agora já pode ser chamado com mais segurança de liberal, o antagonismo posto entre instituições e lideranças populistas, ou mais genericamente entre os modelos representativo e participativo de democracia. Vale salientar que essa polaridade não é inventada na América do Sul, mas assume conotações próprias com a versão periférica do institucionalismo, isto é, aquele que é aplicado em países fora do centro, onde

\footnotetext{
14 Nos debates travados entre liberais e populistas, nome freqüentemente dado para os desenvolvimentistas nos Estados Unidos, sobretudo após o New Deal, a relação com a democracia se invertia. Em meados do século XX, eram os liberais muitas vezes os acusados de prejudicarem o regime democrático (BRINKLEY, 1998). Já correntes mais liberais ou institucionais, evidentemente, afirmavam que somente com o liberalismo a democracia sobreviveria por causa de sua natureza menos moralista ou prescritiva. Contudo, mesmo entre os mais liberais do institucionalismo original nunca houve uma incompatibilidade intransponível de um conceito de democracia muito ligado ao povo com outra definição mais referida às regras, ainda que essa última seja superior (RIKER, 1982).
}

originalmente é desenvolvido ${ }^{14}$.

Afora o fato de ser menos sofisticado, o institucionalismo periférico tem como principal peculiaridade ser um dos responsáveis por alimentar o surgimento do que mais teme, ou seja, o populismo, simplesmente ao pretender de maneira inadvertida uma aplicação fora de contexto em países sul-americanos ou mesmo em outros lugares, onde há distintas tradições, culturas políticas e, o que é mais relevante, grandes assimetrias sociais. Esse efeito perverso do institucionalismo ou do liberalismo pode não ser exclusividade da periferia, mas é nela que se tem manifestado nos últimos anos, de acordo com esse mesmo raciocínio, que não é necessariamente verdadeiro. Como vimos nas duas seções anteriores do trabalho, o enfraquecimento do neoliberalismo e a ascensão de novas lideranças de perfil mais nacionalista não trouxeram de volta, pelo menos na maior parte dos casos, o populismo, conforme sua própria definição, ainda que a crítica liberal assim insista.

Antes de tudo, é preciso perceber que a tensão contemporânea não se dá entre populismo (ou neopopulismo) e neoliberalismo, mas entre democratização e liberalização. Essa desordem analítica tem prejudicado bastante grande parte das interpretações sobre as mudanças verificadas nas últimas décadas. Uma falsa contradição entre populismo e neoliberalismo impede de serem vistos os aspectos democráticos em jogo. A própria definição de neopopulismo já é muito problemática porque, sendo ela aplicada a um tipo de populismo liberal, os movimentos mais recentes, como o de Chávez e Morales, simplesmente não podem ser colocados na mesma categoria. Muito menos podem ser vistos de uma perspectiva do populismo clássico, a não ser que se considere viável hoje retroceder décadas e ignorar meio século de história, entre o fenômeno original e sua cópia gêmea contemporânea. Igualmente parece absurda a hipótese de que o populismo é uma constante na região, variando apenas de conteúdo um mais nacionalista e liberal do que o outro - e situado entre governos militares.

Em resumo, o raciocínio institucionalista liberal é o de que os líderes populistas buscam suplantar as instituições democráticas, enfraquecendo o parlamento, os partidos políticos e mesmo instituições sociais como a Igreja e a imprensa. Dessa forma, essas lideranças seriam altamente nocivas à democracia uma vez que estimulariam 
na população sentimentos avessos a uma verdadeira cultura cívica e de respeito às regras do jogo constitucional. Esse populismo criaria ainda divisões na sociedade, um ambiente de conflito polarizado e maiores riscos ao equilíbrio da economia, tudo isso em razão de uma busca pessoal por poder, que na prática acaba tendo vida curta e deixando uma herança perniciosa.

Essa visão, evidentemente, simplifica e ignora as causas do populismo, impedindo de vê-lo muitas vezes como um sintoma ou efeito de um problema maior e mais complexo (problema segundo a própria lógica institucionalista). Mais do que isso, o institucionalismo periférico não percebe que ele mesmo pode ajudar a produzir lideranças consideradas populistas conforme sua definição. Os institucionalistas dificilmente perguntam-se, por exemplo, por que nascem os líderes populistas ou por que a sociedade adere a esse tipo de discurso e comportamento político, sendo ele, supostamente, antidemocrático e demagógico. Não fazem essas perguntas porque desconsideram problemas sociais básicos da legitimidade. O populismo é resultado, por conseguinte, da incapacidade do institucionalismo periférico para extrapolar a democracia formal, transformando-se também em ganhos mais concretos para a sociedade, como a redução da pobreza e da concentração de renda. As conseqüências populistas do institucionalismo periférico estão, essencialmente, em não criar um Estado de Bem-estar Social, ou pelo menos oferecer respostas mais satisfatórias nessa dimensão.

Com a entrada do povo na política nas últimas décadas do século XX na América do Sul, quando de fato a maioria da população passou a ter o direito à participação eleitoral e à contestação pública $^{15}$, ficou impossível sustentar por muito tempo a democracia apenas em seus aspectos formais sem que mudanças políticas acontecessem.

\footnotetext{
15 Sendo de longe o país mais populoso da região, o Brasil é um exemplo de que a entrada do povo na política ocorreu de forma mais significativa nos anos 1980. Até o golpe militar de 1964 votavam menos de 20\% dos brasileiros. Em 1980 , essa porcentagem cresce para algo um pouco inferior a $50 \%$. Somente com a constituição de 1988 , que permite o voto do analfabeto e de eleitores a partir dos 16 anos, é que quase $70 \%$ dos brasileiros ficam aptos a votar (CARVALHO, 2004). Se há populismo, portanto, esse pode ser um fenômeno mais compatível com a realidade contemporânea.
}

O institucionalismo periférico ao desconhecer essa realidade acabou tornando-se elitista, superficial, e provocando um desgaste das instituições democráticas pelo descrédito, o desânimo e a revolta popular. Teoricamente, o populismo prospera onde o institucionalismo periférico não consegue alcançar, o que não significa dizer que um seja menos democrático que o outro. Na realidade, os eleitores podem enxergar em líderes mais carismáticos uma saída para o desenvolvimento, quando as regras e organizações democráticas tradicionais não realizam bem o seu papel social. Sendo assim, a desconfiança da população não é com a democracia propriamente dita, mas com o que ela tem gerado em termos práticos, tendo em vista um discurso alienado por parte do institucionalismo.

\section{CONCLUSÃO}

O predomínio de pensamentos liberais de toda ordem pode ter contribuído, afinal, para a não discussão devida dos problemas estruturais e mais realistas presentes na América do Sul pós-transição democrática, reproduzindo, assim, uma conivência, ainda que inconsciente, com as mazelas enfrentadas pela região quando menos se esperava que isso fosse ocorrer. Os movimentos de mudança política, observados nas últimas décadas do século XX no continente, não convergiram porque a liberalização econômica (que trabalha com a lógica da competição, da assimetria e do bem privado) respondeu insatisfatoriamente à democratização política (que funciona pela lógica da inclusão, da igualdade e do bem público). As novas lideranças que ascendem ao poder na virada de século são, portanto, consequência de uma maneira plural de as sociedades tentarem reagir pelo voto a essa contradição de sua época.

O crescente processo de liberalização econômica modificou substancialmente a capacidade dos Estados nacionais atenderem às demandas das suas sociedades, e das próprias sociedades atenderem a si mesmas, embora as pressões para isso fossem grandes. A mudança liberal, que com o passar do tempo tornou virtualmente impossível uma volta ao passado, ao statu quo anterior e de maior desenvolvimento, definiu uma trajetória dependente, que os movimentos políticos e sociais posteriores procuram remediar, com todos os obstáculos que isso implica. Os períodos de maior crescimento econômico não trouxeram maior igualdade social; muito pelo contrário. Contudo, a 
partir dos anos 1980 havia a expectativa de que a democracia finalmente viesse a resolver esse problema, o que esteve longe de acontecer, em boa parte porque o Estado nacional enfraqueceu-se e o capitalismo retraiu-se na região.

Em geral, salvo poucas exceções, as novas lideranças sul-americanas que emergem neste início de século não são ultranacionalistas, mas a maior parte delas reluta em aceitar a sensação de fim de festa produzida pela incapacidade do Estado democrático contemporâneo em atender aos anseios por mais bem estar social (COUTINHO, 2006). Apesar de heterogêneo, o movimento político mais recente na região tem em comum o esforço de subordinar a liberalização econômica, que em muitos casos é aparentemente irreversível e pode mesmo estar apenas no começo, a um projeto de desenvolvimento, cujo sucesso é imprevisível e dependerá de muitos fatores. Ao contrário, portanto, das tendências políticas regionais à homogeneização prevalecentes durante os anos 1990 e guiadas pela hegemonia neoliberal, na década seguinte assiste-se a um movimento de diferenciação entre os países sul-americanos, im- pulsionado pelo aprofundamento da democracia e motivo pelo qual é mais difícil identificar neles uma unidade.

A divisão entre institucionalismo e populismo, ou entre neoliberalismo e modelos nacionalistas anacrônicos não deve levar o debate teórico nem as democracias na prática para muito longe. Os movimentos e contra-movimentos das últimas décadas estão redefinindo a política na América do Sul para o novo século, de uma forma que a resultante final desse processo histórico inédito na região possa vir a configurar tanto um horizonte de prosperidade - em que o desenvolvimento finalmente se realize - quanto um destino menos animador, ou mesmo trágico, seja com a irrupção de retrocessos autoritários, seja com a simples constatação da inviabilidade de um continente estacionado. Sendo assim, embora o desempenho da economia conte bastante, o desafio maior é político, e reside na conciliação entre dois movimentos estruturais que não convergem espontaneamente (a liberalização econômica e a democratização política), por meio de medidas que criem vínculos e atenuem, sem encobrir, as cisões existentes dentro da sociedade.

Marcelo Coutinho (mcoutinho@iuperj.br) é pesquisador associado do Instituto Universitário de Pesquisas do Rio de Janeiro (Iuperj) e coordenador do Observatório Político Sul-Americano (OPSA).

\section{REFERÊNCIAS BIBLIOGRÁFICAS}

AXTMANN, R 1997. Liberal Democracy into the Twenty-First-Century : Globalization, Integration and the Nation State. Manchester : Manchester University.

BALDWIN, D. A. 1993. Neorealism and Neoliberalism : The Contemporary Debate. New York : Columbia University.

BRINKLEY, A. 1998. Liberalism and Its Discontents. Cambridge : Harvard University.

CARVALHO, J. M. 2004. Fundamentos da política e da sociedade brasileira. In: AVELAR, A. \& CINTRA A. O. (org.). Sistema politico brasileiro : uma introdução. Rio de Janeiro: Fundação Konrad Adenauer.

COUTINHO, M. 2005. Crises institucionais e mudanças política na América do Sul. Rio de Janeiro. Tese (Doutorado em Ciência Políti- ca). Instituto Universitário de Pesquisas do Rio de Janeiro.

COUTINHO, M. 2006. Democracias andinas : chegando tarde à festa. Artigo apresentado no V Encontro da Associação Brasileira de Ciência Política $(\mathrm{ABCP})$, realizado em Belo Horizonte de 26 a 29 de julho.

CRAWFORD, R. 1996. Regime Theory in the Post-Cold War World : Rethinking the Neoliberal Approach to International Relations. Aldershop : Dartmouth.

DIAMOND, L. \& PLATTNER, M. 1996. The Global Resurgence of Democracy. Baltimore : Johns Hopkins University.

FUKUYAMA, F. 1992. O fim da história e o último homem. Rio de Janeiro : Rocco. 
HALL, P. \& TAYLOR, R. 1996. Political Science and the Three New Institutionalism. Political Studies, Cambridge, v. 44, n. 5, p. 936-957, Dec.

HAGGARD, S. \& KAUFMAN, R. R 1995. The Political Economy of Democratic Transitions. Princeton : Princeton University.

HOROWITZ, D. 1996. Comparing Democratic Systems. In : DIAMOND, L. \& PLATTNER, M. F. (eds.). The Global Resurgence of Democracy. $2^{\text {nd }}$ ed. Baltimore : Johns Hopkins University.

HOFMEISTER, W. 2002. Dadme un balcón y el país es mio : liderazgo político en América Latina. Rio de Janeiro : Fundação Konrad Adenauer.

HUNTINGTON, S. P. 1994. A terceira onda : a democratização no final do século XX. São Paulo : Ática.

LAMOUNIER, B. 1994. A democracia brasileira de 1985 à década de 90 : síndrome da paralisia hiperativa. In : VELOSO, J. P. R. (org.). Governabilidade, sistema político e violência urbana. Rio de Janeiro : J. Olympio.

LATHAM, R. 1997. The Liberal Moment: Modernity, Security and the Making of Postwar International Order. New York : Columbia University.

LIMA, M. R. S. \& COUTINHO, M. 2005. Globalização, regionalização e América do Sul. Análise de Conjuntura OPSA, Rio de Janeiro, n. 6, maio.

LiMA, M. R. S. \& COUTINHO, M. 2006. Integração Moderna. Análise de Conjuntura $O P S A$, Rio de Janeiro, n. 1, jan.

LIMA JR., O. B. 1997. Instituições políticas democráticas : o segredo da legitimidade. Rio de Janeiro : J. Zahar.

LINZ, J. \& STEPAN, A. 1996. Problems of Democratic Transition and Consolidation. Baltimore : Johns Hopkins University.
LODOLA, G. 2004. Neopopulismo na América Latina. Rio de Janeiro : Fundação Konrad Adenauer.

MAINWARING, S. \& SCULLY, T. R. 1994. A Institucionalização dos sistemas partidários na América Latina. Dados, Rio de Janeiro, v. 37, n. 1, p. 43-79.

NAÍM, M. 1995. Latin America : The Second Stage of Reform. In : DIAMOND L. \& PLATTNER M. F. (org.). Economic Reform and Democracy. Baltimore : Johns Hopkins University.

POLANYI, K. 1980. A grande transformação : as origens da nossa época. Rio de Janeiro : Campus.

RIKER, W. H. 1982. Liberalism Against Populism : a Confrontation between the Theory of Democracy and Theory of Social Choice. San Francisco : W. H. Freeman.

SHIN, D. C. 1994. On the Third Wave of Democratization : A Synthesis and Evaluation of Recent Theory and Research. World Politics, Baltimore, v. 47, n. 1, p. 135-170, Oct.

SHUGART, M. \& CAREY, J. 1992. Presidents and Assemblies : Constitutional Design and Electoral Dynamics. Cambridge : Cambridge University.

SOLA, L. 1998. Idéias econômicas, decisões políticas : desenvolvimento, estabilidade e populismo. São Paulo : USP.

STEINMO, S. (ed.). 1992. Structuring Politics : Historical Institutionalism in Comparative Analysis. Cambridge : Cambridge University.

STOKES, S. C. 2001. Mandates and Democra$c y$ : Neoliberalism by Surprise in Latin America. Cambridge : Cambridge University.

WEYLAND, K. G. 1996. Neopopulism and Neoliberalism in Latin America : Unexpected Affinities. Studies in Comparative International Development, v. 32, n. 3. 